the herbage and the stock afford a useful guide to the skilled farmer, but more accurate and quantitative information is necessary for the true comparison of different systems of management. The accurate assessment of yield presents many difficulties, as estimates obtained by continuous cutting to simulate grazing are misleading, since the period and intensity of actual grazing have very far-reaching effects on the sward. In order, therefore, to simulate grazing conditions as closely as possible, experiments of somewhat complex design are necessary, in which there is sufficient replication to permit grazing over the greater part of the experimental period, with infrequent cuts for the actual determination of yield. The type of stock used and variation in seasonal conditions also play their part in complicating the problem.

In the open discussion at the end of the symposium, the question was raised as to the possibility of laying down some clear directions for the practical man in the management of his sward. From the nature of the case, however, this is an impossibility, as the problems are so complex and the correct methods of management are so diverse. Treatments that are effective in one place, on one type of soil or under certain climatic conditions may be quite unsuccessful elsewhere or in other seasons. Careful observation of the effect of grazing on the sward, together with intelligent use of the results of such observation, are essential for the successful production of first-class pastures providing feed of high nutritive value. Furthermore, recent developments in the improvement of wild hill pastures along economic lines have opened up great possibilities for extended and profitable grazing, provided the active co-operation of the interested farming community is forthcoming.

WinifRed E. Brenchley.

\title{
Zoological Expedition to the Oasis of Siwa, Egyptian Libya
}

\section{By Joseph Omer-Cooper, Rhodes University College, Grahamstown, South Africa}

$\mathrm{T}$ HE Armstrong College Expedition to Siwa, consisting of Dr. Malcolm Cameron, Mr. C. L. Smith and myself was financed by the Royal Society, the Godman Exploration Fund, the Percy Sladen Trust, the British Museum (Natural History) and the Armstrong College Research Fund. Its object was the study of a typical Libyan oasis. We left England in March and returned in October 1935, after spending six months in the Libyan Desert and achieving all our objectives. Transfer from the staff of the Department of Zoology, Armstrong College, Newcastle-on-Tyne, to Grahamstown, South Africa, has been the principal cause of delay in presenting a preliminary report of the Expedition's results.

Siwa is watered by more than two hundred wells and springs. These in many cases flow into storage reservoirs from which the gardens are irrigated. The irrigation waters ultimately flow into pools or lakes from which there is no outlet. These are saline, and if large are known as 'birkets'. The water of the springs is thermal, the bottom water varying from $25^{\circ}$ to $29^{\circ} \mathrm{C}$. The salinity, which is slightly more variable, appears to be affected by the proximity of the birkets. In Siwa the larger springs, in which concentration by evaporation was negligible, had a chlorine content of 0.685-1.475 gm. chlorine per litre. The water contains little oxygen. Smith examined water from pipe wells, so obtaining pure samples of the subterranean water, and found only 0.105 c.cm. oxygen per litre. The water is supersaturated with gas which is more than 97 per cent nitrogen ; the residue being oxygen, carbon dioxide and inert gases. As the springs in several other Egyptian oases have the same peculiarities, it is probable that the water is derived from one great subterranean source.

The North African subterranean waters contain a considerable fauna, but no subterranean forms have been recorded from Egypt. This curious fact is adequately explained by the small oxygen content. This also explains the absence of the indigenous Siwan Cyprinodont fish from the larger springs, and the failure of Dr. H. Faouzi to introduce Tilapia into these springs, which appear excellently suited to them.

In certain springs the Cyprinodonts have the swim bladder much swollen and are unable to submerge. Some fish are almost globular. This is no doubt due to the water being supersaturated with nitrogen. 
Siwa was notorious for immense swarms of mosquitos. It was this, in part, which caused us to choose it for investigation. In $1930 \mathrm{Dr}$. Zoghib started an ingenious and successful anti-mosquito campaign. The indigenous Cyprinodont was present in a few of the springs and streams only, and these were much overgrown with reeds, rushes and other vegetation. Dr. Zoghib had the springs and ditches cleaned, and introduced the fish into those not already containing them. Fortunately for us, during his one year of duty at Siwa, he was unable to deal with all the springs, and by the time we arrived many of these had been long neglected, so that we were able to study the primitive conditions. While we were there, Dr. Zoghib was again sent to Siwa as medical officer and continued his work. In this he was aided by the successful introduction of Tilapia by Dr. Faouzi. Before we left, the mosquito breeding places had been almost eliminated.

The introduction of Tilapia by Dr. Faouzi in 1932 has already had an effect. In certain slowflowing springs, they have multiplied greatly. The change produced is the most striking ecological effect, produced by a single organism, which I have seen. The plants have disappeared and with them the Cyprinodonts, Mollusca and insects; even the Crustacea have been almost eliminated; Cladocera are absent and Copepods and Ostracods are scarce. The water, clear in similar springs in which Tilapia are absent, is cloudy and contains numerous flagellates, Protozoa and rotifers. The fish feed on the mud. Within a few years it is probable that they will have exterminated the greater part of the aquatic fauna.

Most of the birkets are very saline, and at the most contain a few Artemia. At Baharein in the East Lake, there were numbers of minute Hydrophilid beetles but nothing else. The water was cloudy, unpleasant smelling, and had a specific gravity at $60^{\circ} \mathrm{F}$. of $1 \cdot 1498$. It is possible that the beetles lived on drowned insects. In an inlet fresh water flowed over the salt water and contained fish. Smith found that the surface temperature was $27 \cdot 2^{\circ} \mathrm{C}$., but it rose rapidly and towards the bottom reached $52 \cdot 9^{\circ} \mathrm{C}$. His observations here and at Siwa show that this temperature gradient was due to solar radiation in the absence of convection currents. At Sitra, springs rose in the lake and the fresh-water spread for some distance over the surface. In these springs were fish which appeared to feed on the Artemia living in the saline water. The Birket El Gessabaia had a specific gravity at $60^{\circ} \mathrm{F}$. of only 1.0357 and contained a number of marine organisms including diatoms, algæ, Cardium edule var., Mytilus minimus, Pirenella conica and Balanus sp. The Cardium and Balanus were recent but we found no living specimens, although we obtained living Mytilus and Pirenella. This fauna is similar to that of the Birket Qarun, and may have been introduced by birds.

In searching our material from $\mathrm{El} \mathrm{Gessabaia} \mathrm{and}$ some other localities for algæ, Dr. Kathleen Blackburn discovered Foraminifera. These were sent to Mr. Heron Allen, who reported that Trochammina, Miliolina, Reophax, Discorbina and Gromia were present. Some of the species he believes to be identical with those described by L. Gauthier Lièvre from the lakes of the Oued Rhin. None of the species are common Mediterranean forms. This fact, coupled with their occurrence in such widely separated localities, suggests that they may have had a different origin from the recent marine immigrants of El Gessabaia. It is possible that they are very ancient relicts.

It is very generally believed that much of the desert fauna rstivates. My experience of the Somali desert made me sceptical of this and, despite much adverse criticism, we made the summer our chief collecting time. In this we were justified, for, contrary to the general belief, insects proved most numerous in July and August. During the heat of the day there was a striking absence of insects in the open desert, although Hymenoptera were numerous in the oasis. In the evenings and at night, however, insects and arachnids abounded. It is this, no doubt, which has given rise to the popular belief that the fauna æstivates.

One of the objects of the Expedition was to find out whether Siwa is a nodal point in the bird migration. Our observations were sufficient to convince me that it is not. The birds cross the desert on a wide front. The concentration which occurs in the oases is due to the infiltration of stragglers, marooned in the desert.

The insect fauna appeared to be Ethiopic rather than Mediterranean; although, as was to be expected, a considerable proportion consisted of widely distributed forms. The dominant groups were Odonata, Orthoptera, Neuroptera and Hymenoptera: Lepidoptera were also abundant, but Coleoptera and Diptera were scarce. Ancient forms appeared to predominate in the desert regions: Thysanura, for example, were numerous. The shifting sands of the desert, like those of the sea, appear to form a refuge for archaic forms of life.

Towards the end of our stay at Siwa, we rarely obtained species not previously captured. This gives us reason to hope that our material is adequate to give a true picture of the ecology of Siwa, and that when the collections have been worked out our results will be reasonably complete. 